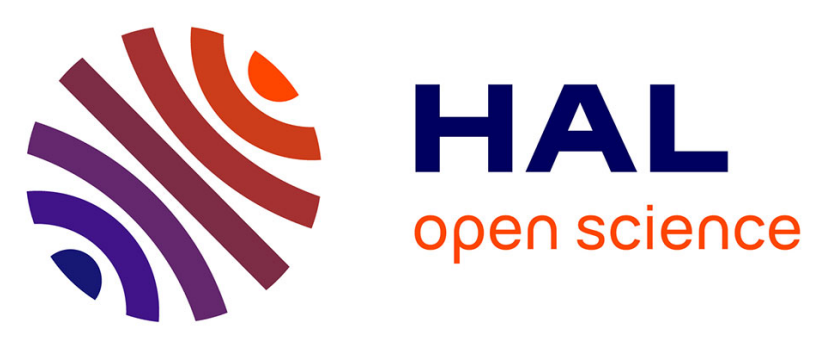

\title{
Fabrication of transparent thin film of octahedral molybdenum metal clusters by electrophoretic deposition
}

\author{
T.K.N. Nguyen, F. Grasset, B. Dierre, C. Matsunaga, Stéphane Cordier, P. \\ Lemoine, N. Ohashi, T. Uchikoshi
}

\section{To cite this version:}

T.K.N. Nguyen, F. Grasset, B. Dierre, C. Matsunaga, Stéphane Cordier, et al.. Fabrication of transparent thin film of octahedral molybdenum metal clusters by electrophoretic deposition. ECS Journal of Solid State Science and Technology, 2016, 5 (10), pp.R178-R186. 10.1149/2.0291610jss . hal01398036

\section{HAL Id: hal-01398036 \\ https://hal-univ-rennes1.archives-ouvertes.fr/hal-01398036}

Submitted on 18 Aug 2020

HAL is a multi-disciplinary open access archive for the deposit and dissemination of scientific research documents, whether they are published or not. The documents may come from teaching and research institutions in France or abroad, or from public or private research centers.
L'archive ouverte pluridisciplinaire HAL, est destinée au dépôt et à la diffusion de documents scientifiques de niveau recherche, publiés ou non, émanant des établissements d'enseignement et de recherche français ou étrangers, des laboratoires publics ou privés. 
archives-ouvertes

\title{
Fabrication of transparent thin film of octahedral molybdenum metal clusters by electrophoretic deposition
}

\author{
T.K.N. Nguyen, F. Grasset, B. Dierre, C. Matsunaga, Stéphane Cordier, P. \\ Lemoine, N. Ohashi, T. Uchikoshi
}

\section{To cite this version:}

T.K.N. Nguyen, F. Grasset, B. Dierre, C. Matsunaga, Stéphane Cordier, et al.. Fabrication of transparent thin film of octahedral molybdenum metal clusters by electrophoretic deposition. ECS Journal of Solid State Science and Technology, 2016, 5 (10), pp.R178-R186. 10.1149/2.0291610jss . hal01398036

\section{HAL Id: hal-01398036 https://hal-univ-rennes1.archives-ouvertes.fr/hal-01398036}

Submitted on 18 Aug 2020

HAL is a multi-disciplinary open access archive for the deposit and dissemination of scientific research documents, whether they are published or not. The documents may come from teaching and research institutions in France or abroad, or from public or private research centers.
L'archive ouverte pluridisciplinaire HAL, est destinée au dépôt et à la diffusion de documents scientifiques de niveau recherche, publiés ou non, émanant des établissements d'enseignement et de recherche français ou étrangers, des laboratoires publics ou privés. 


\title{
Fabrication of Transparent Thin Film of Octahedral Molybdenum Metal Clusters by Electrophoretic Deposition
}

\author{
T. K. N. Nguyen, ${ }^{a, b}$ F. Grasset, ${ }^{c, d}$ B. Dierre, ${ }^{c, d}$ C. Matsunaga, ${ }^{b}$ S. Cordier, ${ }^{e}$ P. Lemoine, ${ }^{e}$ \\ N. Ohashi, ${ }^{\mathrm{c}, \mathrm{d}}$ and T. Uchikoshi ${ }^{\mathrm{a}, \mathrm{b}, \mathrm{d}, \mathrm{z}}$ \\ ${ }^{a}$ Graduate School of Chemical Sciences and Engineering, Hokkaido University, Sapporo, Japan \\ ${ }^{b}$ Materials Processing Unit, National Institute for Materials Science, Tsukuba, Japan \\ ${ }^{c}$ Optical and Electronic Materials Unit, National Institute for Materials Science, Tsukuba, Japan \\ ${ }^{d}$ Laboratory for Innovative Key Materials and Structures, UMI 3629 CNRS - Saint-Gobain - NIMS, National \\ Institute for Materials Science, Tsukuba, Japan \\ ${ }^{e}$ Institut des Sciences Chimiques de Rennes, UMR 6226 CNRS- University of Rennes 1, France
}

\begin{abstract}
Thin films of octahedral molybdenum metal clusters $\left(\mathrm{Mo}_{6}\right)$ were fabricated on indium tin oxide (ITO) glass slides by the electrophoretic deposition (EPD) technique. The solubility of the $\mathrm{Cs}_{2} \mathrm{Mo}_{6} \mathrm{Br}_{14}$ cluster compounds, which are composed of $\left[\mathrm{Mo}_{6} \mathrm{Br}_{8}{ }_{8} \mathrm{Br}_{6}^{\mathrm{a}}\right]^{2-}$ units associated with two cesium cations, in different solvents was investigated in order to achieve a welldispersed colloidal solution of the $\mathrm{Mo}_{6}$ cluster units that was stable during the following EPD process. Distilled water, ethanol, 1-propanol, acetone, methyl-ethyl ketone (MEK) and acetyl acetone were selected as the dispersing media of the $\mathrm{Cs}_{2} \mathrm{Mo}_{6} \mathrm{Br}_{14} \mathrm{Cluster}$ compounds. Homogeneous, transparent $\mathrm{Mo}_{6}$ cluster films with prominent luminescent properties were obtained by the EPD when dissolving $\mathrm{Cs}_{2} \mathrm{Mo}_{6} \mathrm{Br}_{14}$ into the MEK and acetyl acetone solutions. The obtained $\mathrm{Mo}_{6}$ cluster films were examined by investigating the thickness (color 3D laser spectroscopy), the morphology (FE-SEM), the Br/Mo ratio (XRF), and the crystallographic parameters variation (XRD). The optical emission properties were characterized by UV-Vis spectroscopy, FL spectroscopy and micro PL spectroscopy. The thickness of the $\mathrm{Mo}_{6}$ cluster films changed depending on the kind of the solvents. The atomic ratio of the Mo and Br elements in the $\mathrm{Mo}_{6}$ cluster-based unit were relatively maintained during the dispersion and deposition in the MEK solution. The UV-Vis absorption spectra exhibited a high transparency in the visible light range $(500-850 \mathrm{~nm})$ accompanied by many peaks due to light interference in the wavelength range from $400 \mathrm{~nm}$ to $2000 \mathrm{~nm}$. The emission intensity of the Mo ${ }_{6}$ cluster film deposited in MEK slightly decreased during continuous irradiation of $325 \mathrm{~nm}$ laser light for $600 \mathrm{~s}$.
\end{abstract}

Metal cluster units are molecules containing two or more metal atoms which are connected by direct metal-metal bonds and linked with organic or inorganic species as inner ligands (edge-bridging or face-capping positions) and apical ligands (terminal position). The metal cluster units exhibit interesting photochemical, ${ }^{1-6}$ redox $^{7,8}$ and conducting ${ }^{9,10}$ properties that are applicable in many fields such as energy, photocatalysis or biotechnology. The nature and number of metal atoms, and the inner and apical ligands affect the number of valence electrons on the clusters, which changes the intrinsic properties of the clusters and thus their physical properties. ${ }^{11}$ For instance, the electron transport properties progressively shift from a dielectric characteristic in cluster-based halides to semiconducting and superconducting characteristics in the cluster-based chalcogenides. ${ }^{12}$ Among all the transition metal atom clusters, octahedral cluster-based units have attracted a lot of attention due to their wide range of physical properties. The $\mathrm{M}_{6} \mathrm{~L}_{8}{ }_{8} \mathrm{~L}_{6}^{\mathrm{a}}(\mathrm{M}=\mathrm{Mo}, \mathrm{W}, \mathrm{Re} ; \mathrm{L}=$ halogen, chalcogen or functional groups; $\mathrm{L}^{\mathrm{i}}=$ face-capping inner ligand; $\mathrm{L}^{\mathrm{a}}=$ terminal apical ligand) face-capped cluster unit is more chemically stable and has a higher oxidation potential than the $\mathrm{M}_{6} \mathrm{~L}_{12}^{\mathrm{i}} \mathrm{L}_{6}^{\mathrm{a}}(\mathrm{M}=\mathrm{Nb}$, Ta) edge-bridged one. Such face-capped $\mathrm{M}_{6} \mathrm{~L}_{8}^{\mathrm{i}} \mathrm{L}_{6}^{\mathrm{a}}{ }_{6}$ units $\left(\mathrm{M}=\mathrm{Re}, \mathrm{L}^{\mathrm{i}}=\mathrm{S}, \mathrm{L}^{\mathrm{a}}=\mathrm{Se}\right.$ or Te; $\mathrm{M}$ $=$ Mo or $\left.\mathrm{W}, \mathrm{L}^{\mathrm{i}}=\mathrm{L}^{\mathrm{a}}=\mathrm{Cl}, \mathrm{Br}, \mathrm{I}\right)$ exhibit photoluminescence properties characterized by a multicomponent emission from the red to infrared region with a continuous excitation window from ultraviolet (UV) to visible as well as photocatalytic activity. ${ }^{13-15}$ Photoluminescence from red to infrared region is particularly interesting for applications in biotechnologies, lighting and displays. This study focused on the deposition of the $\left[\mathrm{M}_{6} \mathrm{Br}^{\mathrm{i}}{ }_{8} \mathrm{Br}^{\mathrm{a}}{ }_{6}\right]^{2-}$ cluster unit on indium tin oxide (ITO) films. Among the $\mathrm{M}_{6} \mathrm{X}_{8}^{\mathrm{i}} \mathrm{X}_{6}^{\mathrm{a}}(\mathrm{X}=$ halogen) cluster units, the $\left[\mathrm{M}_{6} \mathrm{Br}_{8}{ }_{8} \mathrm{Br}^{\mathrm{a}}{ }_{6}\right]^{2-}$ one is the most chemically stable and it exhibits an oxidation potential sufficiently high to avoid oxidation, which can drastically reduce the luminescent properties by changing the Valence Electron Concentration (VEC). ${ }^{16-22} \mathrm{~A}$ variety of $\mathrm{Mo}_{6}$ cluster-based hybrid materials, originating from the $\mathrm{Cs}_{2} \mathrm{Mo}_{6} \mathrm{X}_{14}$ basic metal cluster compound, has been synthesized by cationic metathesis $\left(\mathrm{TBA}^{16}\right.$ and BEDO-TTF ${ }^{23}$ ) via solution chemistry or replacing the apical ligand

zE-mail: UCHIKOSHI.Tetsuo@nims.go.jp with functional groups ( $\mathrm{PhCN},{ }^{23} \mathrm{~N}_{3}{ }^{24}, \mathrm{SC}_{6} \mathrm{~F}_{4} \mathrm{H}^{25}$ or $\mathrm{C}_{\mathrm{n}} \mathrm{F}_{2 \mathrm{n}+1} \mathrm{COO}^{26}$ ) to enhance the photonic and optoelectronic properties. Due to the molecular nature of the metal cluster compounds, they can be incorporated into different types of matrices to prepare nanocomposites. The synthetic technologies to fabricate the $\mathrm{ZnO}$ support-embedded $\left.\left(\mathrm{nC}_{4} \mathrm{H}_{9}\right)_{4} \mathrm{~N}\right)_{2} \mathrm{Mo}_{6} \mathrm{Br}_{14}$ cluster compound ${ }^{27,28}$ by solution chemistry or $\mathrm{Cs}_{2}\left[\mathrm{Mo}_{6} \mathrm{X}_{14}\right] @ \mathrm{SiO}_{2}$ phosphor nanoparticles by the water-in-oil micro emulsion method ${ }^{29,30}$ have been particularly studied. Original molecular junctions and diodes have been obtained by grafting $\mathrm{Mo}_{6}$ clusters on semiconducting surfaces via organic linkers. ${ }^{31}$ Methyl methacrylate and urethane monomer units were directly polymerized with metal clusters to create photoelectric hybrid materials. ${ }^{32-34}$ The graphenefunctionalized metal cluster has received attention as a potential material in the photocatalysis and energy fields. ${ }^{35,36}$ However, most of these nanocomposite materials, prepared by solution chemistry methods, are powders or bulk materials. There are few reports about the fabrication of thin films composed of metal clusters. . $^{28,34,35}$

Electrophoretic deposition (EPD) has been one of the most popular electrochemical methods to prepare film coatings because of its simple setup, short preparation time and easy control of the film thickness. Many experiments involving a large variety of materials have been performed to optimize the parameters and investigate the deposition mechanisms occurring during the EPD process. ${ }^{37-45}$ Fundamental studies to fabricate thin films of hydroxyapatite, ${ }^{46,47} \mathrm{SiO}_{2},{ }^{48}$ carbon nanotubes, ${ }^{49-51}$ graphene, ${ }^{52} \quad \mathrm{Al}_{2} \mathrm{O}_{3}{ }^{53} \mathrm{TiO}_{2},{ }^{54-56} \mathrm{ZnO},{ }^{57,58}$ forsterite, ${ }^{59}$ metal-organic frameworks (MOFs), ${ }^{60,61}$ ligand-covered metal particles ${ }^{62}$ and a fluorescent $\mathrm{Cu}$ or $\mathrm{Au}$ sheet for light-emitting diodes, ${ }^{63}$ have been performed by EPD. However, to the best of our knowledge, EPD has never been used for the formation of metal cluster thin films on a transparent support, which can be interest for the functionalization of windows with special optical and/or photocatalytic properties. In this study, for the first time, the EPD process was used for fabricating thin films of $\left[\mathrm{Mo}_{6} \mathrm{Br}_{14}\right]^{2-}$ metal clusters. To achieve a homogeneous microstructure, the metal clusters have to be dispersed in a solvent to prepare a uniform solution. We selected several appropriate dispersing media to obtain a stable and transparent suspension for the $\mathrm{Cs}_{2} \mathrm{Mo}_{6} \mathrm{Br}_{14}$ cluster compound. To obtain a thin layer of $\mathrm{Mo}_{6}$ clusters on the ITO glass (anode) by the EPD process, 
the applied voltage and deposition time were optimized. Finally, the $\mathrm{Mo}_{6}$ cluster thin films were fully characterized by color 3D laser microscopy, FE-SEM, XRF, XRD, UV-Vis absorption spectroscopy, FL spectroscopy and micro PL spectroscopy.

\section{Experimental}

Preparation of the molybdenum cluster solution.-The $\mathrm{Cs}_{2} \mathrm{Mo}_{6} \mathrm{Br}_{14}$ cluster compound (Fig. 1a) was synthesized by the reaction between stoichiometric amounts of $\mathrm{CsBr}$ and $\mathrm{MoBr}_{2}$ in a quartz ampoule at high temperatures. ${ }^{16,17}$ First, the as-synthesized $\mathrm{Cs}_{2} \mathrm{Mo}_{6} \mathrm{Br}_{14}$ cluster compound was dissolved in distilled water, ethanol, 1-propanol, acetone, MEK or acetyl acetone solutions at the concentration of $5 \mathrm{~g}$ per liter. Reagent grade chemicals, acetone (99.5\%), methyl ethyl ketone (99\%), acetyl acetone (99\%), 1-propanol $(99.5 \%)$ and ethanol $(99.5 \%)$, were used as received. In the case of ethanol, adding a little amount of water was necessary to prepare the transparent cluster solution (Fig. 1b) for fabricating the transparent $\mathrm{Mo}_{6}$ cluster film. All the solutions were magnetically stirred for fixed duration depending on the kind of the solvents. The distilled water and 1-propanol suspensions were stirred for 24 hours and the acetyl acetone suspension for 6 hours to obtain the stabilization, while the rest for $10 \mathrm{~min}$. The zeta potential and conductivity of the $\mathrm{Mo}_{6}$ cluster suspensions were measured by a zeta-potential analyzer (Malvern Instrument, Ltd., Zetasizer Nano Z: zetapotential-measurable particle size is $5 \mathrm{~nm}-10 \mu \mathrm{m}$ ) after recording the $\mathrm{pH}$ value at room temperature. Though the "operational $\mathrm{pH}$ ", which was measured by a pH meter (TOA Corp., HM-14P) calibrated for an aqueous solvent should be different from the real $\mathrm{p}_{a H}$ in nonaqueous solvents, the operational $\mathrm{pH}$ was used in this study for the sake of convenience. ${ }^{64}$

Fabrication of the thin films by electrophoretic deposition $(\boldsymbol{E P D})$. - Before application of the EPD process, the ITO glass substrates with a surface area of $2.5 \mathrm{~cm}^{2}$ were washed by detergent, then acetone for 30 minutes by sonication. Anodic EPD systems, which include a stainless steel sheet as the cathode and ITO glass as the anode, were connected to a DC power supply (Keithley Instruments, Inc., SourceMeter Model 2400) (Fig. 1c). The EPD was carried out at a constant voltage of 5-50 V for $80 \mathrm{~s}$. During the voltage application, the $\mathrm{Cs}^{+}$cations and $\left[\mathrm{Mo}_{6} \mathrm{Br}_{14}\right]^{2-}$ anions were deposited on the stainless steel cathode and the ITO glass anode, respectively. The deposition area of the clusters was approximately $1.5 \mathrm{~cm}^{2}$. The applied voltages and deposition time of the EPD were separately optimized for each solvent. The deposit weight was determined by subtracting the weight of the ITO glass before and after EPD. The prepared thin films were slowly dried in air and used for characterization of the properties.

Characterization methods.-The thickness of the thin films was measured using a color 3D laser microscope (Keyence VK 9700) equipped with a 408-nm violet laser. The surface morphology of the films and the components of $\mathrm{Mo}, \mathrm{Br}$ and $\mathrm{Cs}$ elements were identified by field-emission secondary electron microscopy (FE-SEM), (S4800, Hitachi High-Technologies Corp.) at $10 \mathrm{kV}$ and an X-ray fluorescence (XRF) measurement (ZSX Primus II, Rigaku Corp.), respectively. The crystal structure of the thin films was identified by X-ray diffraction (XRD) measurement (Altima 3, Rint 2000, Rigaku Corp.) at $40 \mathrm{kV}$ and $30 \mathrm{~mA}$ in the $2 \theta$ angle range from 5 to $55^{\circ}$ with $\mathrm{Cu} \mathrm{K \alpha}$ radiation $(\lambda=0.15405 \mathrm{~nm})$. Optical absorbance of the $\left[\mathrm{Mo}_{6} \mathrm{Br}_{14}\right]^{2-}$ cluster films was measured by UV-Vis-NIR spectroscopy (V570, Jasco Corp.) in the wavelength range of 220 to $2000 \mathrm{~nm}$ at the scan rate of 400 $\mathrm{nm} / \mathrm{s}$. The emission spectra of the cluster films were obtained by high performance fluorescence spectroscopy (FL) (FP8500, Jasco Corp.) connected to a xenon lamp at the scan rate of $500 \mathrm{~nm} / \mathrm{s}$. A micro photoluminescence (PL) system (LabRam HR, Horiba Corp.) with a $325-\mathrm{nm} \mathrm{He}-\mathrm{Cd}$ laser system was used to record the emission peak in the wavelength range of $350 \mathrm{~nm}$ and $1000 \mathrm{~nm}$ and the photo luminescent $(\mathrm{PL})$ profile during the irradiation for $600 \mathrm{~s}$.
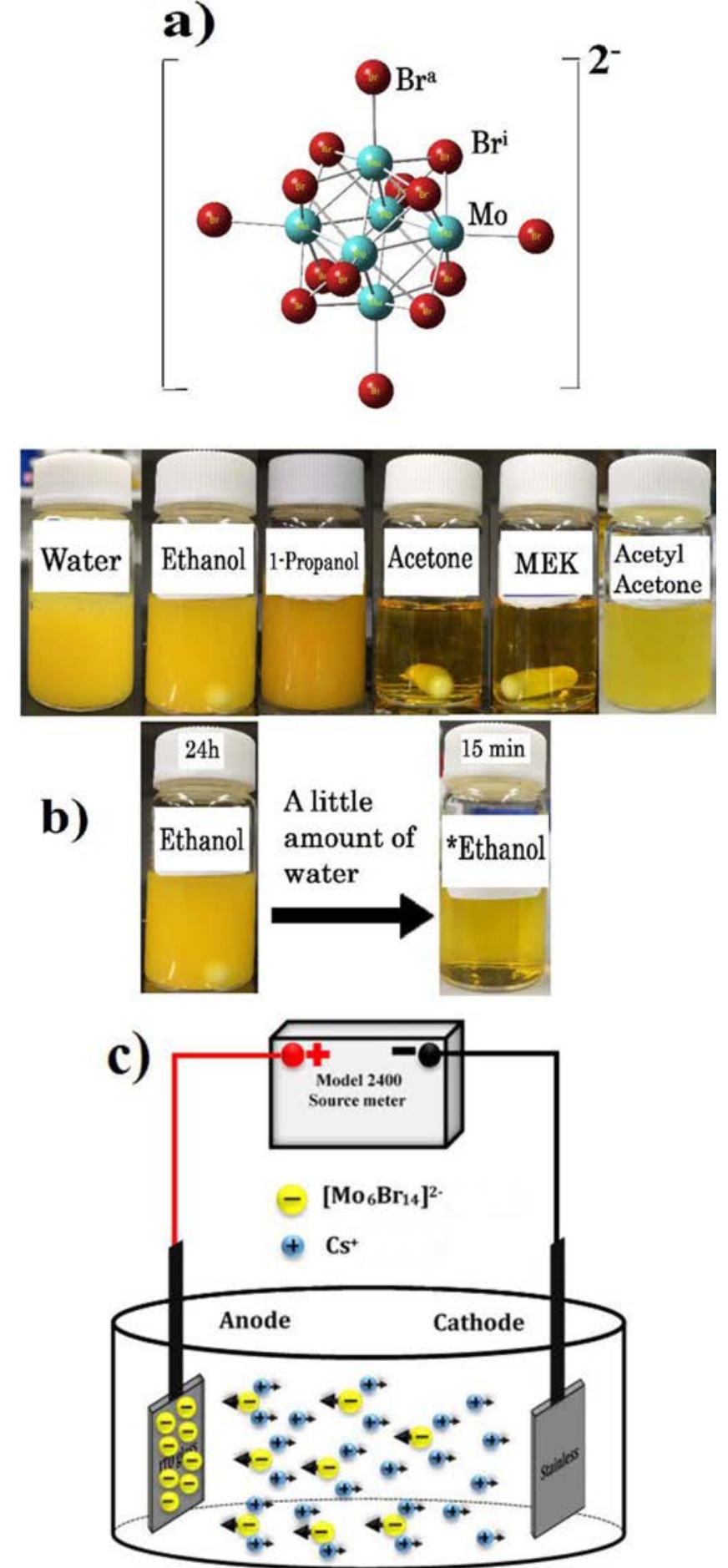

Figure 1. a) The octahedral structure of $\left[\mathrm{M}_{6} \mathrm{Br}^{\mathrm{i}}{ }_{8} \mathrm{Br}^{\mathrm{a}}{ }_{6}\right]^{2-}$ metal cluster; b) Solutions of $\mathrm{Cs}_{2} \mathrm{Mo}_{6} \mathrm{Br}_{14}$ clusters dissolved in distilled water, ethanol, 1propanol, acetone, MEK and acetylacetone; c) Schematic representation of anodic EPD for preparing $\mathrm{Mo}_{6}$ cluster functional thin film.

\section{Results and Discussion}

Zeta potential and conductivity.-Figure 2 shows the electric conductivity and zeta potential of the $\mathrm{Cs}_{2} \mathrm{Mo}_{6} \mathrm{Br}_{14}$ solution. All the solutions showed a negative zeta potential probably due to the existence of partially-dissociated $\left[\mathrm{Mo}_{6} \mathrm{Br}_{14}\right]^{2-}$ units. In the cases of acetone, MEK, acetyl acetone and ethanol, transparent solutions were obtained after stirring, suggesting the dissociation and homogeneous dispersion of 


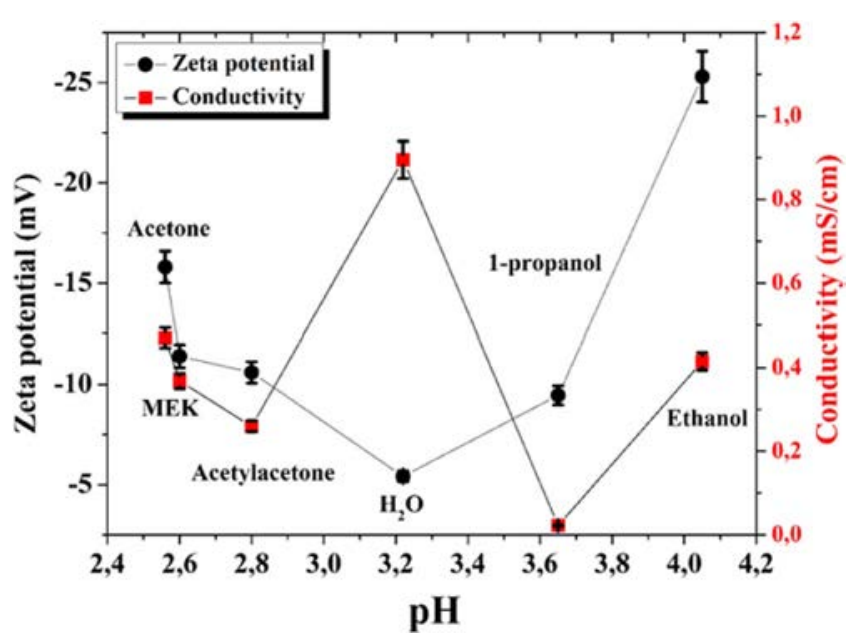

Figure 2. Relation of zeta potential and conductivity versus $\mathrm{pH}$ of the $\mathrm{Cs}_{2} \mathrm{Mo}_{6} \mathrm{Br}_{14}$ solutions from different solvents.

the $\mathrm{Cs}_{2} \mathrm{Mo}_{6} \mathrm{Br}_{14}$ cluster as $\mathrm{Cs}^{+}$and $\left[\mathrm{Mo}_{6} \mathrm{Br}_{14}\right]^{2-}$ in the solvents. The difference in the conductivity was another important factor reflecting the degree of dissociation of the $\mathrm{Cs}_{2} \mathrm{Mo}_{6} \mathrm{Br}_{14}$ clusters into $\mathrm{Cs}^{+}$ions and $\left[\mathrm{Mo}_{6} \mathrm{Br}_{14}\right]^{2-}$ units. It was observed that the conductivity of the distilled water solution reached the highest value $(0.895 \mathrm{mS} / \mathrm{cm})$ while the absolute value of the zeta potential was the lowest $(-5.42 \mathrm{mV})$. It is probable that the $\mathrm{Cs}^{+}$cations with a small size, dissociated from the $\mathrm{Cs}_{2} \mathrm{Mo}_{6} \mathrm{Br}_{14}$ cluster compound, significantly dispersed in water creating a high conductivity in the solution. Consequently, the high mobility of $\mathrm{Cs}^{+}$free ions in water may be the dominant carriers in the solution under the applied electric field, which may reduce the movement of the $\left[\mathrm{Mo}_{6} \mathrm{Br}_{14}\right]^{2-}$ anionic clusters. ${ }^{43}$ The 1-propanol solution has the lowest conductivity $(0.022 \mathrm{mS} / \mathrm{cm})$, which could reduce the mobility of the ions under the applied voltages and thus prevent the $\left[\mathrm{Mo}_{6} \mathrm{Br}_{14}\right]^{2-}$ anions from getting the necessary electrophoretic mobility to move toward the anode. Intermediate values of the conductivity $(0.26-0.47 \mathrm{mS} / \mathrm{cm})$ and zeta potential $(-10.6$ to -25.3 $\mathrm{mV}$ ) were obtained for the acetone, MEK, ethanol and acetyl acetone solutions.

Figure 3 shows the films obtained on the ITO glass anode for the different solutions and their photoluminescence under visible and 324 $\mathrm{nm}$ light. Yellow thin films were obtained from the acetone, MEK, acetyl acetone, and ethanol solutions by the anodic EPD process. The yellow films exhibited photoluminescence with a red color during the irradiation of 324-nm wavelength light. This red luminescence was

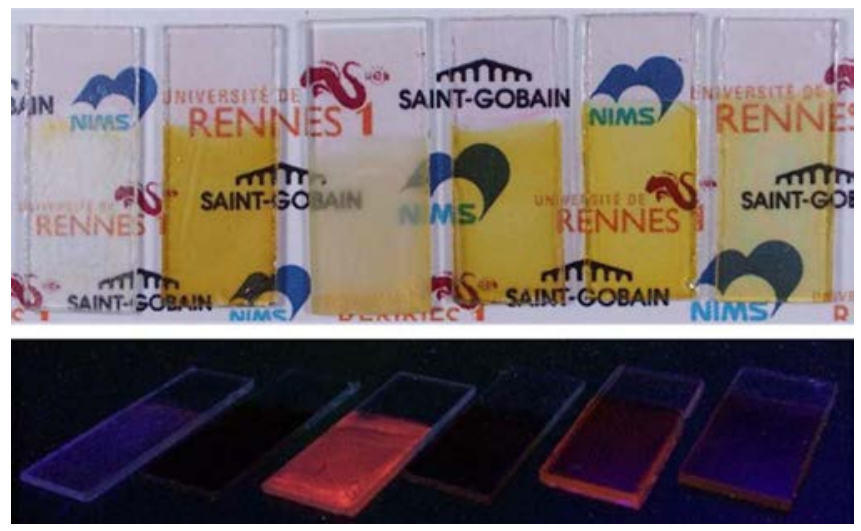

Figure 3. The $\mathrm{Mo}_{6}$ cluster thin films deposited from (left to right) water, ethanol, 1-propanol, acetone and MEK solutions at $15 \mathrm{~V}$ for $20 \mathrm{~s}$ and from acetyl acetone solution at $50 \mathrm{~V}$ for $40 \mathrm{~s}$ (upper), respectively. Image of the luminescence of the cluster thin films irradiated at $324 \mathrm{~nm}$ wavelength (under). a simple first proof of the successful deposition of the $\left[\mathrm{Mo}_{6} \mathrm{Br}_{14}\right]^{2-}$ cluster unit on the ITO glass surfaces.

Figures $4 \mathrm{a}$ and $4 \mathrm{~b}$ show the relation of the initial current density and the total deposited weight versus applied voltage ( $5 \mathrm{~V}-50 \mathrm{~V})$ during the deposition for $30 \mathrm{~s}$ for all the solutions, respectively. When the applied voltage increased, ions in the solution moved faster between the two electrodes, and consequently, the current density increased (Fig. 4a). The highest deposition yield was observed for water solution, while the lowest yield was in the 1-propanol solution, and similar increasing trends for the other solvents. The deposited weight of the films from the water, 1-propanol and acetyl acetone solutions hardly changed while maintaining the amount lower than $0.5 \mathrm{mg} / \mathrm{cm}^{2}$ even by increasing the applied voltages to $50 \mathrm{~V}$ (Fig. 4b). According to Hamaker's mass balance law, the deposition yield of charged particles should be proportional to the applied electric field strength and the current should be proportional to the applied voltage. ${ }^{53}$ The results observed for the films from the MEK, ethanol and acetone solutions were relatively consistent with this law in the range of applied voltages lower than $30 \mathrm{~V}$. However, the deposited weight of the films from the ethanol, acetone, and MEK solutions once reached the maximum at $1.59 \mathrm{mg} / \mathrm{cm}^{2}(25 \mathrm{~V}), 1.62 \mathrm{mg} / \mathrm{cm}^{2}(25 \mathrm{~V})$ and $2.47 \mathrm{mg} / \mathrm{cm}^{2}(30 \mathrm{~V})$, respectively, and then gradually decreased. In general, a high applied voltage increases the migration of the particles to the electrode, and consequently, increase the amount of deposit on the electrode. Accumulation of the clusters on a substrate is achieved by interaction between the clusters and the electrode surface. If the velocity of the clusters to the electrode is too fast, there will not be enough time to make them lose their negative charge by interacting with the substrate; they could be repelled due to the counter force between the clusters on the electrode surface. In addition, at a high velocity, the movement of the particles to the electrode may be disturbed and the collision between the particles when moving may occur, restricting the deposition of the particles closely packed on the electrode. ${ }^{40}$ As a result, the amount of deposit on the films decreased with an applied voltage higher than $30 \mathrm{~V}$. As an exception, the deposited cluster amount was $0.65 \mathrm{mg} / \mathrm{cm}^{2}$ at $50 \mathrm{~V}$ which was more than twice the value at the lower voltages $\left(0.24 \mathrm{mg} / \mathrm{cm}^{2}\right)$ in the case of the acetyl acetone solution. For this reason, the applied voltage of $50 \mathrm{~V}$ was selected to investigate the deposition property only for the acetyl acetone solution. Fifteen V was selected for the films prepared from the other solutions due to most of them obtaining a relative homogeneity over the entire ITO surface. At an applied voltage higher than $15 \mathrm{~V}$, the cluster films started to appear as a U-shaped line at the edge of the ITO surface. The selection of the applied voltage for the films depended on the stabilization and homogeneity of the films.

Figures $4 \mathrm{c}$ and $4 \mathrm{~d}$ show the relation of the current density and deposit weight versus the deposition time. With the increasing deposition time, the current density decreased and the deposit amount sharply increased at the early stage of the deposition. This behavior was recognized in the first $40 \mathrm{~s}$ since there was coagulation between the clusters. However, detachment and removal of the deposited cluster agglomerates were observed in the beaker during the EPD after $40 \mathrm{~s}$. This tendency was remarkable in the water solution. The maximum deposition weight were similarly recorded for the films prepared from the MEK $\left(2.25 \mathrm{mg} / \mathrm{cm}^{2}\right)$, acetone $\left(1.65 \mathrm{mg} / \mathrm{cm}^{2}\right)$ and ethanol $\left(1.85 \mathrm{mg} / \mathrm{cm}^{2}\right)$ solutions in $40 \mathrm{~s}$ at $15 \mathrm{~V}$ (Fig. $4 \mathrm{~d}$ ). Although the film from the acetyl acetone solution was still formed at $50 \mathrm{~V}$, the deposition weight was not very much at the highest value $\left(1.12 \mathrm{mg} / \mathrm{cm}^{2}\right)$. The deposition amount of the clusters in the water and 1-propanol solutions was very small and the maximum value was not clearly observed. During the EPD process, the applied potential is reduced by potential drops at the electrodes (electrode potential) and in the suspension. ${ }^{53}$ Though the potential applied between the two electrodes is maintained constant, the effective potential applied to the suspension decreases due to the ohmic loss by the deposition layer on the electrode,$^{38,40}$ causing a decrease in the electrophoretic mobility and pressing force of the charged species onto the counter electrode. Following the scaling theory, ${ }^{65}$ if no electrochemical interaction occurs, the particle charge would be balanced with the charge of the electrode. 

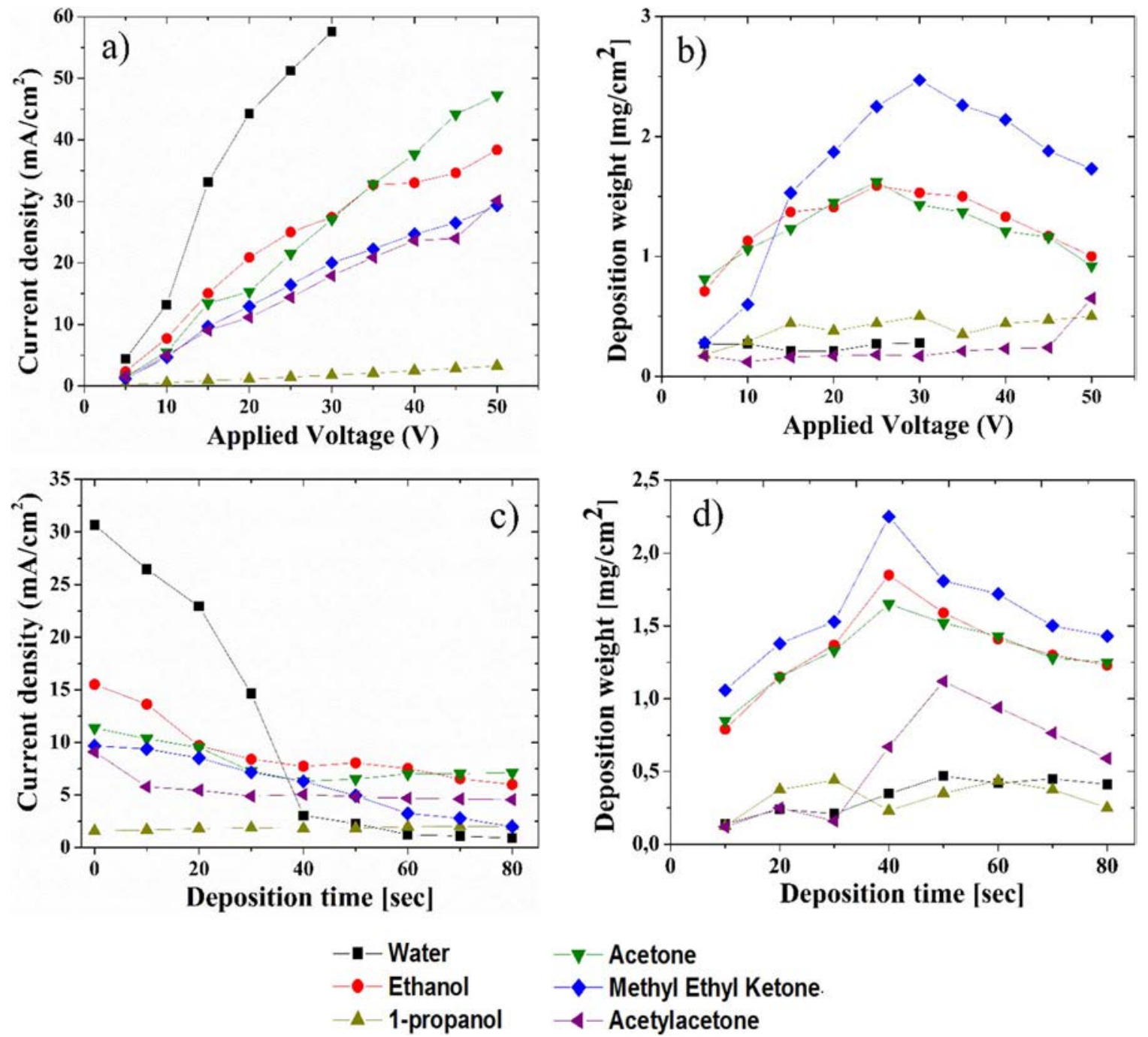

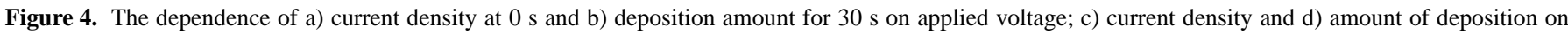

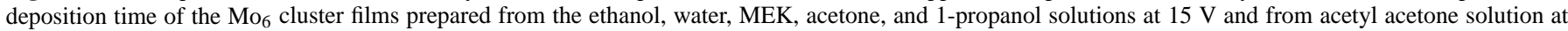
$50 \mathrm{~V}$.

Estrelia-Lopez et al. have suggested that the particles are immobilized on the electrode by interacting with irreversible ions produced from the electrical reaction and dipole interaction. ${ }^{66}$ In the case of the $\left[\mathrm{Mo}_{6} \mathrm{Br}_{14}\right]^{2-}$ anions, during the EPD process, the small cluster groups $(100 \mathrm{~nm})$ of the first layers are immobilized by balancing the charge with the $\mathrm{H}_{3} \mathrm{O}^{+}$cations and the charge on the electrode, along with a dipole interaction in the electric field. Between the clusters, there exist van der Waals interactions between the halogen ligands. On the other hand, cations could diffuse into the still negatively charged cluster deposit to balance the charge and produce an ion interaction. In addition, Bohmer interpreted that the aggregation decreased if the ion strength increased. ${ }^{67}$ At the longer deposition time, when the distance between the large negative cluster particles is shorter than the diameter of the cluster particle, an electrostatic repulsion between the clusters will be generated. In summary, there are three possible reasons for breaking up the cluster layers at a long deposit time: i) the field strength decreases because the cluster layers acting as a resistance, ii) the electrostatic repulsion increases between the large negative particles, and iii) the ion interaction strength increases because the free cations that diffused in the outside cluster layer increased.

It has been explained that EPD is a combination of two processes: (i) electrophoresis, the migration of charged particles toward an oppositely-charged electrode under the influence of an electric field, and (ii) deposition, the coagulation of particles to a dense mass at the surface of electrode. Zeta potential and conductivity mainly affect the electrophoresis of surface charged particles. Higher zeta potential of the particles and lower conductivity of the solvent are usually necessary conditions, however, deposition yield cannot be estimated only from the zeta potential and conductivity data because the sticking probability of the particles reaching the electrode is often not $100 \% .{ }^{38}$ In the EPD process, electrolysis of water has been considered to be harmful due to gas evolution; however, our recent studies show that small amount of water contamination in organic solvents contributes the improvement of adhesion of particles on an electrode substrate. We are guessing that hydroxide-like compounds are formed at an electrode surface and they might play a role of glue to improve the adhesion of particles. In this study, precise control of the amount of water in the different solvents was not performed; therefore, we could not systematically explain the difference of the deposition characteristics in the different solvents from the limited measurements.

By considering the results of the zeta potential, conductivity, current density and deposition amount during the EPD process, especially in terms of the stabilization of the solutions and the uniformity of the films, the optimized applied voltage and time were determined at $15 \mathrm{~V}$ for $10-30 \mathrm{~s}$ for the acetone, MEK and ethanol solutions and at $50 \mathrm{~V}$ for $40 \mathrm{~s}$ for the acetyl acetone solution. The $\mathrm{Cs}_{2} \mathrm{Mo}_{6} \mathrm{Br}_{14}$ suspensions in MEK, ethanol, acetone and acetyl acetone solutions seem 

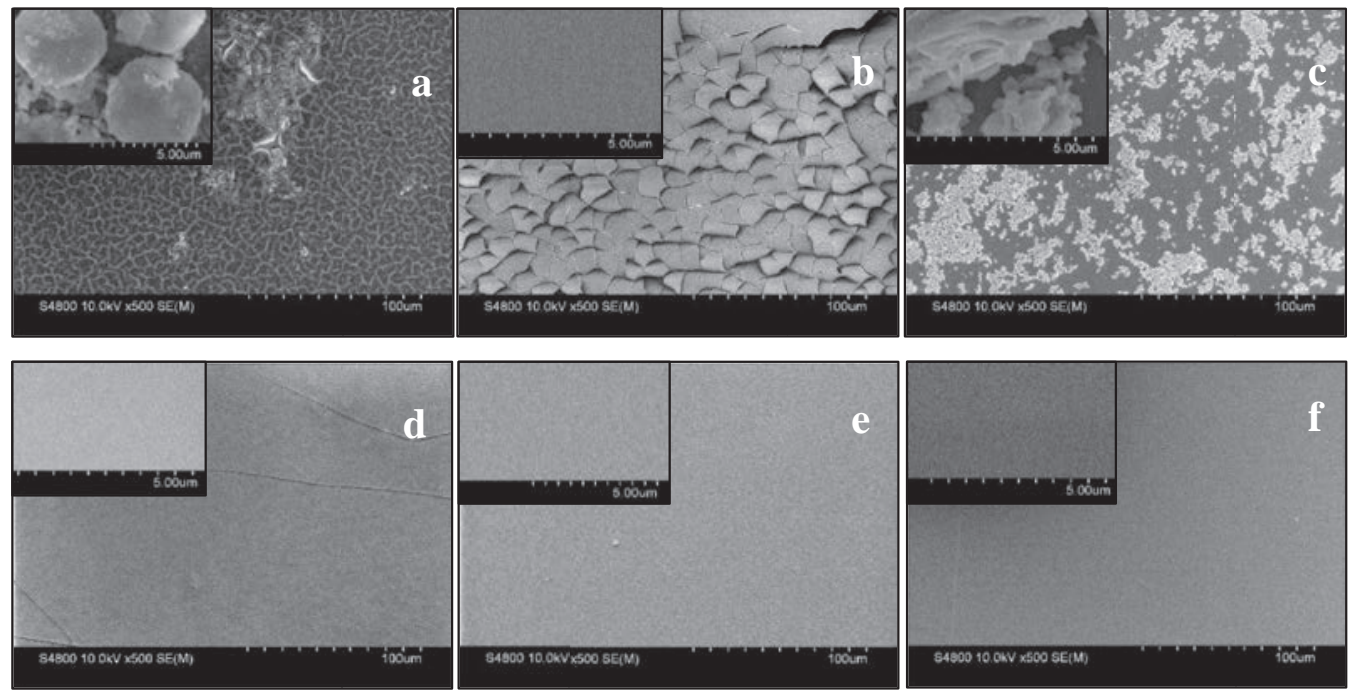

Figure 5. FE-SEM morphology on the surface of the $\mathrm{Mo}_{6}$ cluster films prepared from a) distilled water; b) ethanol; c) 1-propanol; d) acetone; e) MEK solutions at $15 \mathrm{~V}$ for $20 \mathrm{~s}$; and f) acetyl acetone solution at $40 \mathrm{~V}$ for $10 \mathrm{~s}$, with 500 and 10,000 magnifications.

relevant for the fabrication of a homogeneous film during the EPD process.

Morphology and structure.-The film parameters using the optimized parameters were characterized by the thickness measurement, morphology observation, $\mathrm{Br} / \mathrm{Mo}$ atomic ratio measurement and XRD analysis of the crystallographic parameters. Figure 5 shows the surface images of the fabricated layers on the ITO glass observed by FE-SEM. It could be seen that the $\mathrm{Mo}_{6}$ cluster films prepared from the water and 1-propanol solutions have small grains of cluster crystals with the size about $5 \mu \mathrm{m}$ and are embedded on the surface of the ITO glass. The film prepared from the 1-propanol solution has a higher density and smaller grain size than that from the water solution. The $\mathrm{Cs}_{2} \mathrm{Mo}_{6} \mathrm{Br}_{14}$ cluster was very easily dissolved in the acetone, ethanol, MEK, and acetyl acetone solutions; consequently, the deposit surfaces showed smooth and homogeneous morphology and no presence of any cluster crystals under the observation at 500 and 10,000 magnifications. However, some of the thin films, especially in the case of ethanol, were cracked and peeled off from the substrates after drying in air.

The thickness of the thin films prepared from the different solvents was measured by color 3D laser microscopy at a high resolution. The results are shown in Table I. For the ethanol, acetone and MEK solutions, the thickness of about $1 \mu \mathrm{m}$ was attained in the first $10 \mathrm{~s}$ and it increased to $2 \mu \mathrm{m}$ when the deposition time was $20 \mathrm{~s}$. In contrast, the thickness of the film from the acetyl acetone solution was very thin $(0.76 \pm 0.04 \mu \mathrm{m})$ even though the EPD was performed at a high

Table I. Thickness and Br/Mo atomic ratio of the $\mathrm{Mo}_{6}$ cluster films prepared from different solvents.

\begin{tabular}{ccc} 
Sample & Thickness $(\mu \mathrm{m})$ & Br/Mo atomic ratio \\
\hline $\mathrm{Cs}_{2} \mathrm{Mo}_{6} \mathrm{Br}_{14}$ & - & 2.20 (theoretical) \\
Water 20s & N/A & N/A \\
1-Propanol 20s & N/A & N/A \\
AA(40s, 50V) & $0.76 \pm 0.04$ & 3.41 \\
Ethanol 10s & $0.82 \pm 0.07$ & 2.96 \\
Ethanol 20s & $2.00 \pm 0.14$ & 1.74 \\
Acetone 10s & $0.86 \pm 0.13$ & 2.09 \\
Acetone 20s & $1.76 \pm 0.09$ & 1.92 \\
MEK 10s & $1.12 \pm 0.08$ & 2.73 \\
MEK 20s & $1.85 \pm 0.17$ & 2.26 \\
MEK30s & $2.11 \pm 0.09$ & 2.18
\end{tabular}

applied voltage $(50 \mathrm{~V})$ and for a longer deposition time $(40 \mathrm{~s})$. When acetyl acetone was used as the dispersion medium, the thickness of the deposited layer was the thinnest although the obtained suspension was stable. The low conductivity of the suspension in the acetyl acetone could be the reason for this behavior. The suitable thickness of the cluster film could be regulated by altering the deposition time and applied voltage during the EPD process.

Pure $\mathrm{Mo}_{6}$ bromide cluster films, which have not been yet reported in the literature to the best of our knowledge, were successfully fabricated using the EPD process. The results of XRF measurements indicated that no Cs elements are present in the deposited film. Interestingly, the atomic ratio of $\mathrm{Br} / \mathrm{Mo}$ of the powder measured by XRF was not significantly different from those of the theoretical index while the ratios of $\mathrm{Br} / \mathrm{Mo}$ in the thin films fabricated in $10 \mathrm{~s}$ were higher than the theoretical ratio of the $\mathrm{Cs}_{2} \mathrm{Mo}_{6} \mathrm{Br}_{14}$ powder. This implies that $\mathrm{Br}$ rich layers were prepared on the ITO glass in the first $10 \mathrm{~s}$ of the EPD process. The $\mathrm{Br}^{-}$anion would originate from the $\mathrm{Cs}_{2} \mathrm{Mo}_{6} \mathrm{Br}_{14}$ cluster compound during the dissolving, stirring and deposition in the solvents. The solvent could partially dissociate the $\mathrm{Cs}_{2} \mathrm{Mo}_{6} \mathrm{Br}_{14}$ cluster compound and separate the $\mathrm{Br}^{-}$ions out of the apical ligand positions of the octahedral blocks, reducing the negative charge on the surface of the $\mathrm{Cs}_{2} \mathrm{Mo}_{6} \mathrm{Br}_{14}$ cluster. This reaction might be accelerated by the applied electric field. For the $20 \mathrm{~s}$ deposition time, the $\mathrm{Br} / \mathrm{Mo}$ atomic ratios of the films prepared from the acetone (1.92) and ethanol (1.74) solutions were remarkably lower than those of the original $\mathrm{Cs}_{2} \mathrm{Mo}_{6} \mathrm{Br}_{14}$ powder (2.20), while it reached a stable value for the films from the MEK solution (2.26 at $20 \mathrm{~s}$ and 2.18 at $30 \mathrm{~s}$ ). In solution, the compound is fully dissociated into the $\mathrm{Cs}^{+}$cations and $\left[\mathrm{Mo}_{6} \mathrm{Br}_{8}{ }_{8} \mathrm{Br}_{6}^{\mathrm{a}}\right]^{2-}$ anions; however, it is known that $\left[\mathrm{Mo}_{6} \mathrm{Br}_{8}{ }_{8} \mathrm{Br}_{6}^{\mathrm{a}}\right]^{2-}$ can react with solvent to form species like $\left[\mathrm{Mo}_{6} \mathrm{Br}_{8}{ }_{8} \mathrm{Br}^{\mathrm{a}}{ }_{5} \text { (solvent) }{ }^{\mathrm{a}}\right]^{1-}$ and one $\mathrm{Br}^{-}$, or $\left.\left[\mathrm{Mo}_{6} \mathrm{Br}_{8}{ }_{8} \mathrm{Br}^{\mathrm{a}}{ }_{4} \text { (solvent) }\right)_{2}{ }^{\mathrm{a}}\right]^{0}$ and two $\mathrm{Br}^{-}$ions. It has also been reported that the apical $\mathrm{Br}$ atoms of the $\mathrm{Mo}_{6}$ clusters are easily replaced by $\mathrm{H}_{2} \mathrm{O}$ or $\mathrm{OH}^{-}$molecules to form the compound of $\mathrm{Mo}_{6} \mathrm{Br}^{\mathrm{i}}{ }_{8} \mathrm{Br}^{\mathrm{a}}{ }_{4}\left(\mathrm{H}_{2} \mathrm{O}\right)_{2}$ or $\left[\mathrm{Mo}_{6} \mathrm{Br}^{\mathrm{i}}{ }_{8} \mathrm{Br}^{\mathrm{a}}{ }_{6-\mathrm{x}}(\mathrm{OH})_{\mathrm{x}}\right]^{2-},{ }^{68,69}$ respectively. The decrease in the $\mathrm{Br} / \mathrm{Mo}$ ratio reduces with the increasing deposit time means that the structure of the octahedral clusters is continually transferred at different deposition times under the impact of the electric field. In addition, during the EPD process, dissociated $\mathrm{Cs}^{+}$cations probably migrate to the cathode and deposit there, while the electrolysis of water molecules takes place at the anode to generate " $\mathrm{H}^{+}$" cations, combining with $\mathrm{H}_{2} \mathrm{O}$ molecules to produce $\mathrm{H}_{3} \mathrm{O}^{+}$cations. These $\mathrm{H}_{3} \mathrm{O}^{+}$cations would neutralize the negative charge of the $\mathrm{Mo}_{6}$ clusters leading to deposition on the surface of the ITO glass substrate. The framework of the $\mathrm{Mo}_{6}$ octahedral clusters depends on the ratio and classification 


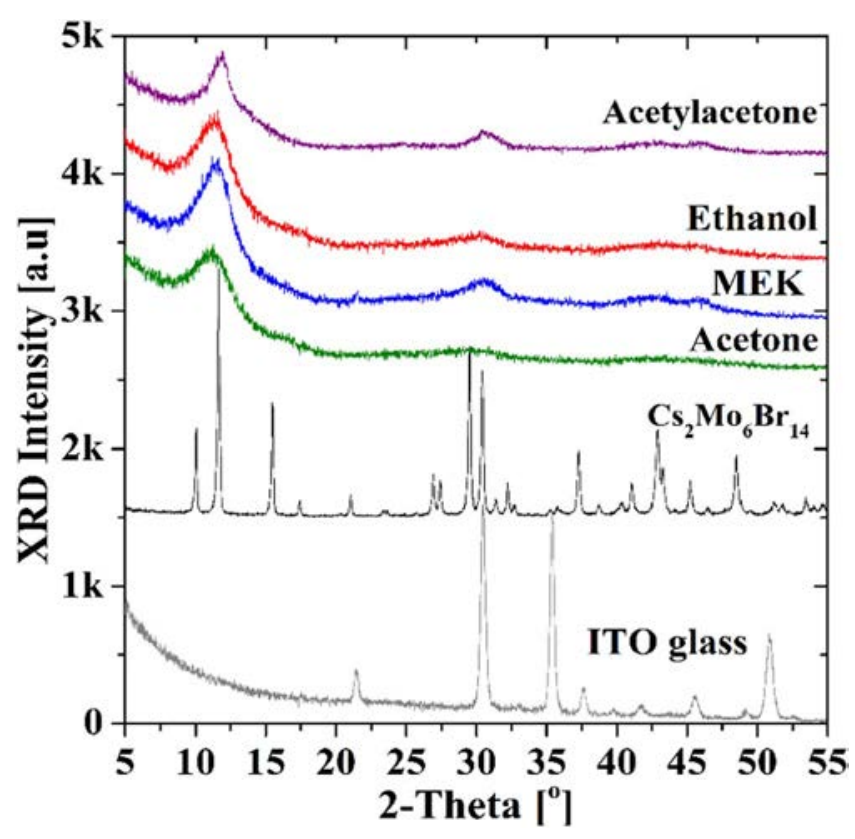

Figure 6. X-ray diffraction diagram of ITO glass, the $\mathrm{Cs}_{2} \mathrm{Mo}_{6} \mathrm{Br}_{14}$ powder and the thin films prepared by the EPD from ethanol, acetone, MEK solutions at $15 \mathrm{~V}$ for $20 \mathrm{~s}$ and acetyl acetone solution at $50 \mathrm{~V}$ for $40 \mathrm{~s}$.

of anions and counter cations. Based on these hypotheses, a general formulation of the cluster particles inside layer could be tentatively estimated as $\left[\mathrm{H}_{3} \mathrm{O}^{+}\right]_{6+\mathrm{x}+2}\left[\mathrm{Br}^{-}\right]_{6+\mathrm{x}}\left[\left(\mathrm{Mo}_{6} \mathrm{Br}_{8} \mathrm{Br}_{6-\mathrm{x}}(\mathrm{OH})_{\mathrm{x}}\right)^{2-}\right]$. For example, the $\mathrm{Br} / \mathrm{Mo}$ ratio of the film prepared from acetyl acetone is 3.41 , which is close to twenty $\mathrm{Br}$ atoms corresponding to six Mo atoms, thus the formation of the octahedral cluster structure could be suggested to be $\left[\mathrm{H}_{3} \mathrm{O}^{+}\right]_{8}\left[\left(\mathrm{Br}^{-}\right)_{6}\left(\mathrm{Mo}_{6} \mathrm{Br}_{14}\right)^{2-}\right]$ or $\left[\mathrm{H}_{3} \mathrm{O}^{+}\right]_{14}\left[\left(\mathrm{Br}^{-}\right)_{12}\left[\left(\mathrm{Mo}_{6} \mathrm{Br}_{8}(\mathrm{OH})_{6}\right)^{2-}\right]\right.$ with $\mathrm{x}=0$ or 6 .

Figure 6 shows XRD patterns of the ITO glass, $\mathrm{Cs}_{2} \mathrm{Mo}_{6} \mathrm{Br}_{14}$ powder and thin films prepared by the EPD from the ethanol, acetone, and MEK solutions at $15 \mathrm{~V}$ for $20 \mathrm{~s}$, and from the acetyl acetone solution at $50 \mathrm{~V}$ for $40 \mathrm{~s}$. Diffraction peaks of the $\mathrm{Cs}_{2} \mathrm{Mo}_{6} \mathrm{Br}_{14}$ powder are obvious and the signal to noise ratio is strong, while the peaks are unclear and broad for the deposited films. Here, it must be noted that no oxide phases were detected from the thin film XRD measurements in this study. The broadening of the diffraction peaks around the $2 \theta$ angles of $11^{\circ}$ and $31^{\circ}$, observed on the patterns of the $\mathrm{Mo}_{6}$ cluster films prepared from the acetone, MEK, acetyl acetone and ethanol solutions, is probably due to the smaller crystallite sizes in the films compared to powder but are also strongly influenced by the thickness of the films and local distortion of the crystal structure from the ITO interface. The dissolution of the $\mathrm{Cs}_{2} \mathrm{Mo}_{6} \mathrm{Br}_{14}$ powder, the cationic metathesis and the solvation implies a packing arrangement of cluster units in the deposited films different from that observed in the $\mathrm{Cs}_{2} \mathrm{Mo}_{6} \mathrm{Br}_{14}$ powders. It could be suggested that the original frameworks of the $\mathrm{Mo}_{6}$ cluster were modified in the film deposited on the ITO glass by substituting the counter cations as already discussed. The stability of the octahedral structure of the $\mathrm{Mo}_{6}$ clusters in a solvent was very important regarding the prominent luminescent property. Therefore, MEK would be the most suitable solvent for dissolving the $\mathrm{Cs}_{2} \mathrm{Mo}_{6} \mathrm{Br}_{14}$ cluster compound and maintaining the stability and transparency of the solution during the EPD process.

Optical properties.-The homogeneity, transmittance and optical properties of the $\mathrm{Mo}_{6}$ cluster thin films were clearly confirmed by UV-Vis spectroscopy. Figure 7 shows the UV-Vis spectra measured for the ITO glass, the cluster solution dissolved in the MEK solution, and the films fabricated from the different solutions. As illustrated in the UV-Vis absorption spectra, the films prepared from the water and 1-propanol solutions showed similar profiles to the ITO glass; the adsorption edge wavelength is $375 \mathrm{~nm}$ (Fig. 7b). On the other hand, two strong adsorption peaks at $330 \mathrm{~nm}$ and $382 \mathrm{~nm}$ were recognized for the $\mathrm{Cs}_{2} \mathrm{Mo}_{6} \mathrm{Br}_{14}$ clusters dissolved in the MEK solution (Fig. 7a), while the light absorptions at the wavelengths lower than $580 \mathrm{~nm}$ were recorded for the films from the ethanol, acetone, MEK and acetyl acetone solutions (Figs. 7b, 7c, 7d, and 7e). The UV-Vis absorption spectra of the $\mathrm{Mo}_{6}$ cluster films were the combination of the absorption by the $\left[\mathrm{Mo}_{6} \mathrm{Br}_{14}\right]^{2-}$ clusters and that of the ITO glass. Not only the transparent property, but also the extended absorption wavelength in the visible light range for the cluster functionalized ITO surface would be another positive characteristic of the film as a band pass filter. A significant feature in the UV-Vis absorption spectra of the thin films is the existence of several peaks with different absorption bands in the range from $580 \mathrm{~nm}$ to $2000 \mathrm{~nm}$. The appearance of these peaks originated from the interference phenomena of the incident and reflected lights by the cluster film overlapping with the attenuation peak due to the absorption by the ITO in the wavelength range higher than $580 \mathrm{~nm}$. Therefore, many new strong absorption peaks appeared with gradually increasing intensities. When a film has a good transparency, the interference reflection regularly appears in the absorption spectrum. The interference peaks appeared in the film deposited from the MEK solution for 10 to $30 \mathrm{~s}$ (Fig. 7c), from the ethanol solution for $10 \mathrm{~s}$ (Fig. 7e) and from the acetyl acetone solution for $40 \mathrm{~s}$ (Fig. 7b), showing the homogeneous property of these films while the interference peaks did not appear for the film from the acetone solution (Fig. $7 \mathrm{~d}$ ). The number and position of the interference peaks depend on the thickness of the transparent $\mathrm{Mo}_{6}$ cluster film. Four peaks appeared for the film from the acetyl acetone solution $(0.76 \mu \mathrm{m}$ thick) the same as the film from the ethanol solution $(0.82 \mu \mathrm{m})$, but the number of peaks increased in the film from the MEK solution deposited in $30 \mathrm{~s}$ $(2.11 \mu \mathrm{m})$

The photoluminescence excitation (PLE) is another important property to characterize the $\mathrm{Mo}_{6}$ cluster films prepared on ITO glasses by the EPD process. The PLE spectra of the $\mathrm{Cs}_{2} \mathrm{Mo}_{6} \mathrm{Br}_{14}$ powder and the $\mathrm{Mo}_{6}$ cluster films under a xenon lamp are shown in Figure 8. In the excitation spectra of the $\mathrm{Cs}_{2} \mathrm{Mo}_{6} \mathrm{Br}_{14}$ powder shown in Fig. 8a, excitation peaks sharply appear at $370 \mathrm{~nm}$, low at $275 \mathrm{~nm}$ and broad at around $430 \mathrm{~nm}$ and $480 \mathrm{~nm}$. Most of the cluster thin films exhibited peaks at the wavelengths of $275 \mathrm{~nm}, 370 \mathrm{~nm}$ and $430 \mathrm{~nm}$, like the cluster powder, except for the film from acetone which did not show any clear peaks. It was also predicted that the high symmetry of the $\left[\mathrm{Mo}_{6} \mathrm{Br}_{14}\right]^{2-}$ clusters was partially broken because of the prominent solubility in acetone. Figures $8 \mathrm{~b}$ and $8 \mathrm{c}$ show emission spectra monitored in the range from $500 \mathrm{~nm}$ to $850 \mathrm{~nm}$ when the films were excited at the $275 \mathrm{~nm}$ and $370 \mathrm{~nm}$ wavelengths, respectively. Except for the film from the acetone solution with a significantly low intensity, the other films showed large, broad emission peaks in the visible light range $(685 \mathrm{~nm}-700 \mathrm{~nm})$. The peak position was at $680 \mathrm{~nm}$ for the $\mathrm{Cs}_{2} \mathrm{Mo}_{6} \mathrm{Br}_{14}$ powder, at $685 \mathrm{~nm}$ for the film from the MEK solution and at $690 \mathrm{~nm}$ for the film from the acetyl acetone solution, with relatively strong intensity. As a result, the MEK and acetyl acetone solutions would be good dispersing media for the $\mathrm{Cs}_{2} \mathrm{Mo}_{6} \mathrm{Br}_{14}$ cluster to observe their PL property. The change in the PL excitation and emission spectra could be explained by i) change in the ligands environment, and ii) a higher symmetry of the cluster unit before and after deposition. ${ }^{13}$

The PL property and optical stabilization of the $\mathrm{Mo}_{6}$ clusterthin films under continuous irradiation by a $325 \mathrm{~nm}$ laser for $600 \mathrm{~s}$ are shown in Figure 9. All the films display strong emissions in the range from 550 to $1000 \mathrm{~nm}$, which is characteristic of the $\mathrm{Cs}_{2} \mathrm{Mo}_{6} \mathrm{Br}_{14}$ cluster compounds.

In Figure 9a, it seems that two main emission peaks appeared at $757 \mathrm{~nm}$ and $761 \mathrm{~nm}$ for the films prepared from the ethanol solution $(0.82 \mu \mathrm{m}$ thick), at $707 \mathrm{~nm}$ and $757 \mathrm{~nm}$ for the films from the acetyl acetone solution $(0.76 \mu \mathrm{m})$, and at $720 \mathrm{~nm}$ and $776 \mathrm{~nm}$ for the films from the MEK solution $(1.12 \mu \mathrm{m})$. When increasing the thickness of the film to $2 \mu \mathrm{m}$, one abroad peak appeared for the films from the ethanol solution $(753 \mathrm{~nm})$ and acetone solution $(723 \mathrm{~nm})$ with a reduced emission intensity. Emission for the films from the MEK 

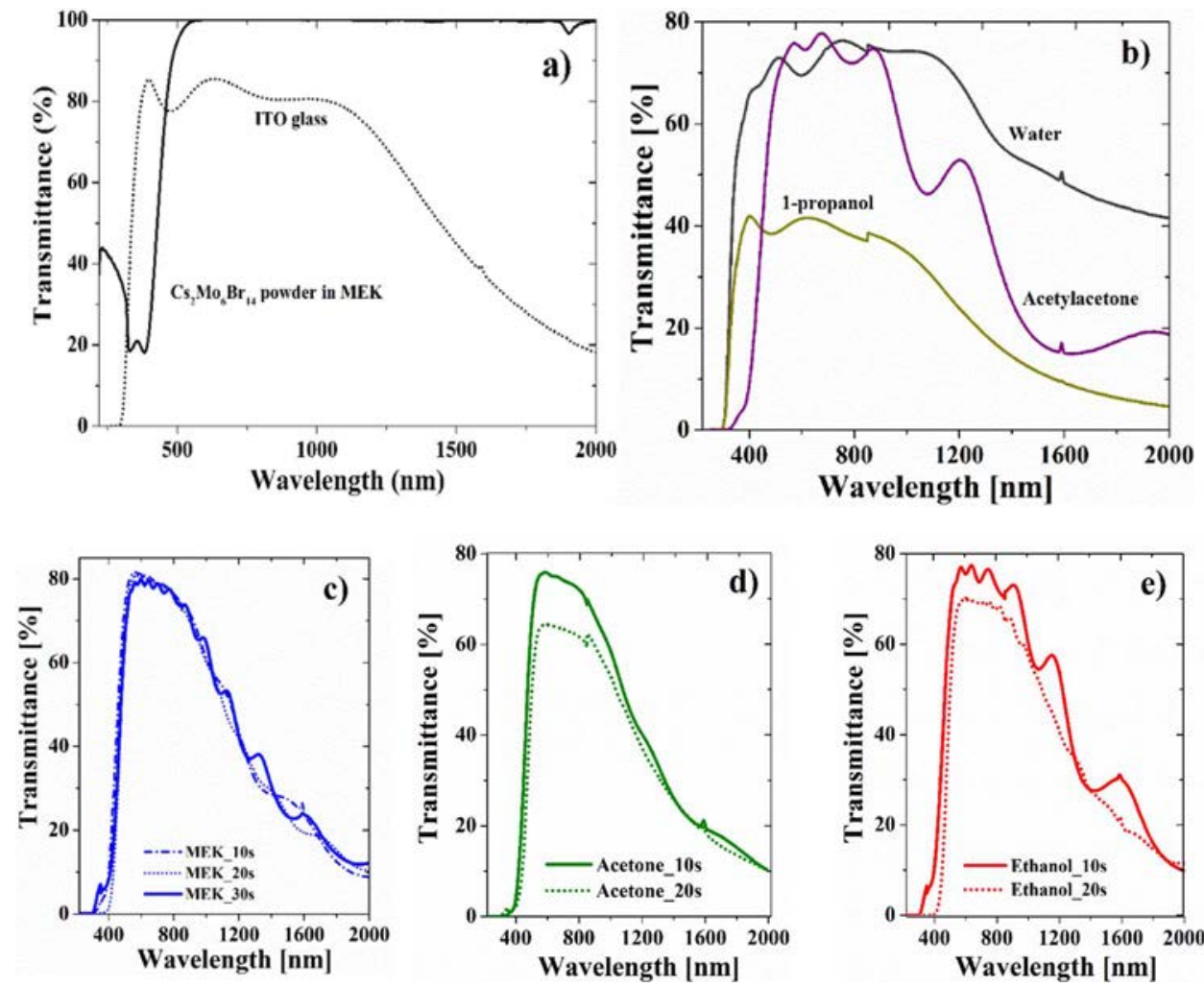

Figure 7. UV-Vis transmission spectra of a) ITO glass, $\mathrm{Cs}_{2} \mathrm{Mo}_{6} \mathrm{Br}_{14}$ powder dissolved in MEK solution, $\mathrm{Mo}_{6}$ cluster films prepared from b) distilled water, 1-propanol and acetyl acetone, c) MEK, d) acetone, and e) ethanol solutions. The $\mathrm{Mo}_{6}$ film from the acetyl acetone solution was prepared by the EPD at 50 $\mathrm{V}$ for $40 \mathrm{~s}$ while the films from the other solutions were prepared at $15 \mathrm{~V}$ for $20 \mathrm{~s}$.
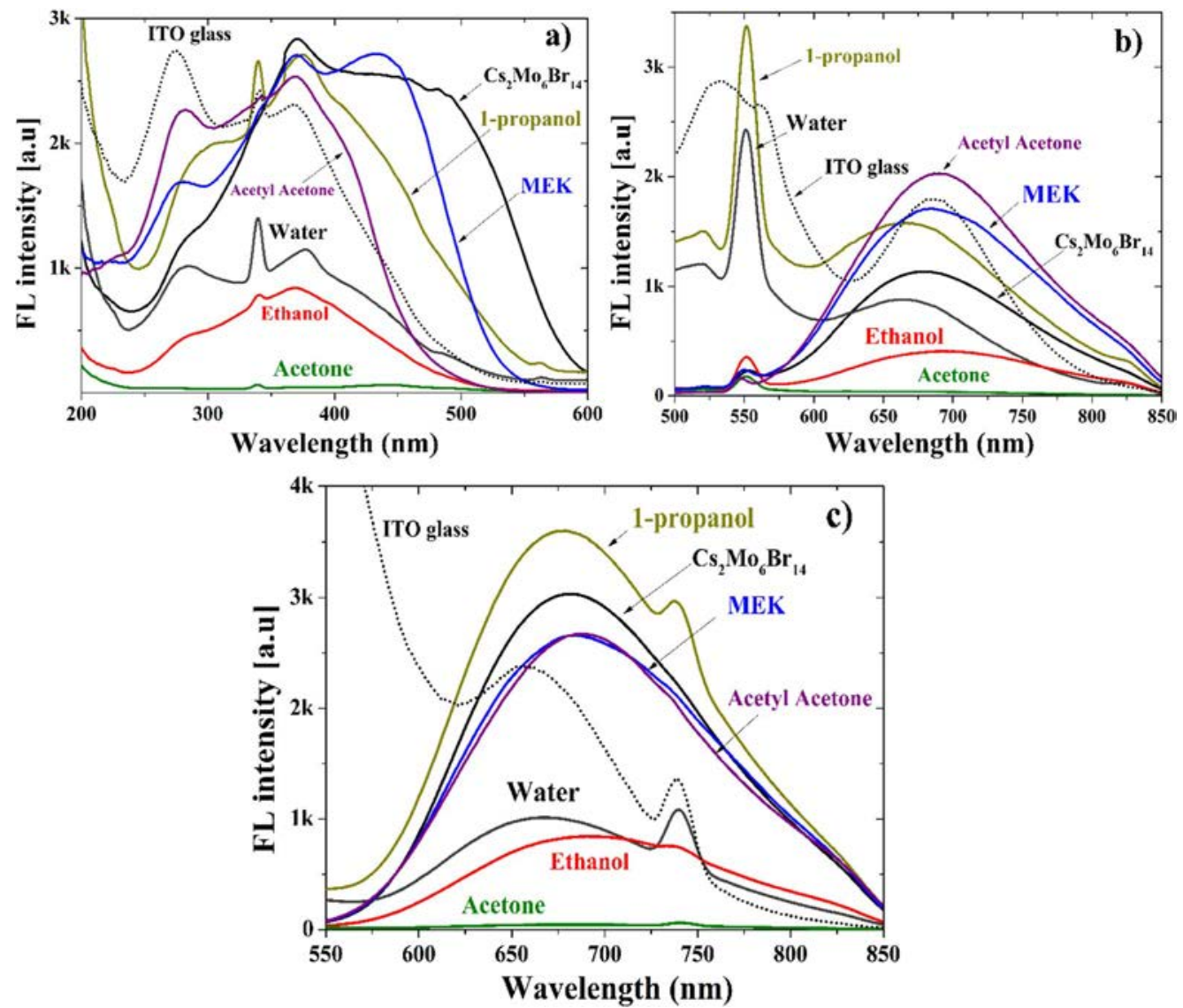

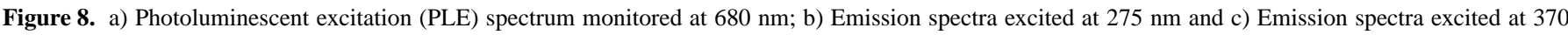

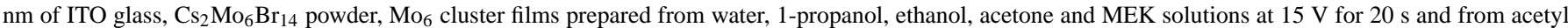
acetone solution at $50 \mathrm{~V}$ for $40 \mathrm{~s}$. 

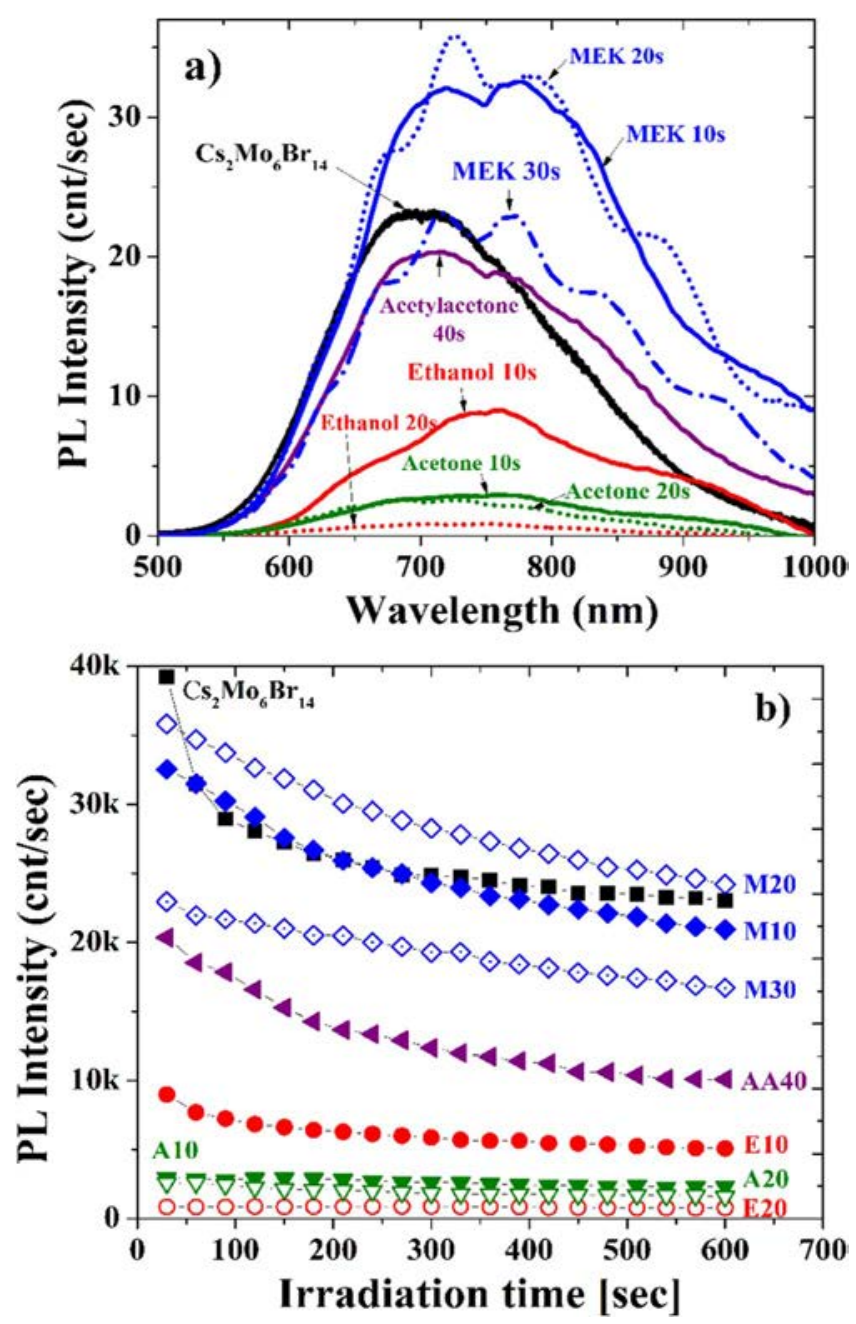

Figure 9. a) Photoluminescence spectroscopy at $325 \mathrm{~nm}$ by excitation laser and b) emitting stabilization of the $\mathrm{Mo}_{6}$ clusterthin films at different emissions by irradiation at $325 \mathrm{~nm}$ laser light for $600 \mathrm{~s}$. The films prepared from the ethanol (E10, E20), acetone (A10, A20) and MEK (M10, M20, M30) solutions fabricated at $15 \mathrm{~V}$ for 10,20 and $30 \mathrm{~s}$, and from acetyl acetone (AA40) solution fabricated at $50 \mathrm{~V}$ for $40 \mathrm{~s}$.

solution included several peaks overlapped at 680, 725, 782 and 858 $\mathrm{nm}$ for a film having a $1.82 \mu \mathrm{m}$ thickness and at $680,716,768,825$ and $916 \mathrm{~nm}$ for the film having a $2.11 \mu \mathrm{m}$ thickness. The appearance of new emission peaks for the homogeneous and thicker films prepared from the MEK solution means a change in the electron excited states of the deposited layer from the as-synthesized powder. The luminescence of the $\left[\mathrm{Mo}_{6} \mathrm{Br}_{8}{ }_{8} \mathrm{Br}^{\mathrm{a}}{ }_{6}\right]^{2-}$ cluster unit exhibited a multicomponent emission resulting from four possible excited states. Thus each phenomenon that changes the geometry of the units (counter cations, solvation effects, defects ...) implies modifications of the shape of the photoluminescence spectra. ${ }^{13}$ The intensity of the PL spectra decreased with time during the continuous irradiation of the $325 \mathrm{~nm}$ laser on the deposited films as shown in Fig. 9b. The PL intensity of the film from the ethanol solution deposited for $10 \mathrm{~s}$ strongly decreased $(23.9 \%)$ in the first $120 \mathrm{~s}$ and was $43.6 \%$ in $600 \mathrm{~s}$ of the irradiation. A similar decreasing trend occurred in the film deposited in $20 \mathrm{~s}$ from the ethanol solution. The PL intensity reduced 50.5\% in 600 $\mathrm{s}$ for the film from the acetyl acetone solution ( $15 \mathrm{~V}$ and $40 \mathrm{~s})$, while there was no obvious change for the film deposited for $10 \mathrm{~s}$ and $20 \mathrm{~s}$ from the acetone solution. Similarly, the film deposited for 10, 20 and $30 \mathrm{~s}$ from the MEK solution reduced $35.7 \%, 31.7 \%$ and $27.2 \%$ in the $600 \mathrm{~s}$ irradiated time, respectively. The PL emission of the film from the MEK solution was more stable than those of the other films at a similar thickness and the emission stabilization was improved corresponding to the increase in the thickness. The appearance of the new peaks and the attenuation of the PL intensity will be related to the impurity states, defects, and/or change in the local cluster geometry which might be introduced during the dissolution and deposition of the clusters. The pathways of the valence electrons are metal-metal charge transfer and metal-ligand-metal charge transition through the localized orbital of the metallic core and ligands. ${ }^{13,70}$ The localized orbitals may stably store the valence electrons. When the amount of the $\mathrm{Mo}_{6}$ clusters on the ITO glass increases, it achieves a close-packed assembly of the localized orbitals between the $\mathrm{Mo}_{6}$ clusters. It is necessary to determine the origin of this behavior of the $\mathrm{Mo}_{6}$ clusters in the future.

\section{Conclusions}

The MEK and acetyl acetone solutions strongly dissolve the $\mathrm{Cs}_{2} \mathrm{Mo}_{6} \mathrm{Br}_{14}$ cluster compound to obtain well dispersed colloid suspensions of $\mathrm{Cs}^{+}$and the $\left[\mathrm{Mo}_{6} \mathrm{Br}_{8}{ }_{8} \mathrm{Br}^{\mathrm{a}}{ }_{6}\right]^{2-}$ cluster unit which can remain stable during the EPD process. Homogeneous and smooth deposited layers of $\mathrm{Mo}_{6}$ clusters containing no $\mathrm{Cs}^{+}$cations were successfully obtained for the first time after optimizing the applied voltage and deposition time. Furthermore, the $\mathrm{Mo}_{6}$ thin films prepared from the MEK and acetyl acetone solutions presented a strong UV-Vis absorption (less than $580 \mathrm{~nm}$ ) with many absorption peaks from 500 $\mathrm{nm}$ to $2000 \mathrm{~nm}$. They also exhibited a strong transparency and phosphorescent emission when excited at the wavelengths of $275 \mathrm{~nm}$ and $370 \mathrm{~nm}$. The PL intensity of the films prepared from the MEK solution was improved with the increasing thickness of the film. The $\mathrm{Mo}_{6}$ cluster films fabricated by EPD still retained the prominent original emission properties. The deposition mechanism of the $\mathrm{Mo}_{6}$ clusters on the ITO glass by the EPD and specific $\mathrm{Mo}_{6}$ octahedral structure will be further explored in the future. The molybdenum octahedral cluster film prepared on the ITO glass would be applicable to the field of optical materials such as LED or solar cell devices. . $^{15,34}$

\section{Acknowledgments}

This study was performed at the National Institute for Materials Science (NIMS) under the collaboration between NIMS (Japan), CNRS (France), RENNES 1 University (France) and Saint-Gobain Company (France). We thank Dr. C. Zhang at NIMS for his help with the EPD experiments.

\section{References}

1. P. C. Ford and A. Vogler, Acc. Chem. Res., 26, 220 (1993)

2. T. G. Gray, C. M. Rudzinski, E. E. Meyer, R. H. Holm, and D. G. Nocera, J. Am. Chem. Soc., 125, 4755 (2003)

3. L. F. Szczepura, J. A. Edwards, and D. L. Cedeño, J. Clust. Sci., 20, 105 (2009)

4. Y. Molard, A. Ledneva, M. Amera-Cortes, V. Circu, N. G. Naumov, C. Mériadec, F. Artzner, and S. Cordier, Chem. Mater, 23, 5122 (2011).

5. M. N. Sokolov, M. A. Mikhailov, K. A. Brylev, A. V. Virovets, C. Vicent, N. B. Kompankov, N. Kitamura, and V. P. Fedin, Inorg. Chem., 52, 12477 (2013).

6. K. Kirakci, P. Kubát, K. Fejfarová, J. Martinčík, M. Nikl, and K. Lang, Inorg. Chem., 55, 803 (2016).

7. T. Yoshimura, K. Umakoshi, Y. Sasaki, S. Ishizaka, H.-B. Kim, and N. Kitamura, Inorg. Chem., 39, 1765 (2000).

8. T. Yoshimura, Z.-N. Chen, A. Itasaka, M. Abe, Y. Sasaki, S. Ishizaka, and N. Kitamura, Inorg. Chem., 42, 4857 (2003).

9. D. Certain and R. Lissillour, Z. Phys. D-Atoms, Morecules and Clusters, 3, 411 (1986).

10. U. Simon, R. Flesch, H. Wiggers, G. Schön, and G. Schmid, J. Mater. Chem., 8, 517 (1998).

11. S. Cordier, Y. Molard, K. A. Brylev, Y. V. Mironov, F. Grasset, B. Fabre, and N. G. Naumov , J. Clust. Sci., 26, 53 (2015).

12. M. Potel, C. Perrin, A. Perrin, and M. Sergent, Mat. Res. Bull., 21, 1239 (1986).

13. K. Costuas, A. Garreau, A. Bulou, B. Fontaine, J. Cuny, R. Gautier, M. Mortier Y. Molard, J. L. Duvail, E. Faulques, and S. Cordier, Phys. Chem. Chem. Phys., 17, 28574 (2015)

14. Y. Zhao and R. R. Lunt, Adv. Energy Mater, 3, 1143 (2013).

15. P. S. Kuttipillai, Y. Zhao, C. J. Traverse, R. J. Staples, B. G. Levine, and R. R. Lunt, Adv. Mater, 28, 320 (2016)

16. K. Kirakci, S. Cordier, and C. Perrin, Z. Anorg. Allg. Chem., 631, 411 (2005). 
17. G. Saito, H. Hosoda, Y. Yoshida, J. Hagiwara, K. Nishimura, H. Yamochi, A. Otsuka, T. Hiramatsu, Y. Shimazaki, K. Kirakci, S. Cordier, and C. Perrin, J. Mater. Chem., 22, 19774 (2012).

18. P. Kumar, S. Kumar, S. Cordier, S. Paofai, R. Boukherroub, and S. L. Jain, RSC $A d v$., 4, 10420 (2014).

19. K. Kirakci, S. Cordier, T. Roisnel, S. Golhen, and C. Perrin, Z. Kristallogr. NCS, 220 $116(2005)$.

20. J. Cuny, S. Cordier, C. Perrin, C. J. Pickard, L. Delevoye, J. Trébosc, Z. Gan, L. Le Pollès, and R. Gautier, Inorg. Chem., 52, 617 (2013).

21. S. Kamiguchi, S. Nagashima, and T. Chihara, Metals, 4, 84 (2014).

22. T. T. Nguyen, J. Jung, X. Trivelli, J. Trébosc, S. Cordier, Y. Molard, L. L. Pollès, C. J. Pickard, J. Cuny, and R. Gautier, Inorg. Chem, 54, 7673 (2015).

23. K. Kirakci, H. Hosoda, S. Cordier, C. Perrin, and G. Saito, J. Solid State Chem., 179, 3628 (2006).

24. A. Barras, S. Cordier, and R. Boukherroub, Appl. Catal. B: Environ., 123-124, 1 (2012).

25. M. N. Sokolov, M. A. Mikhailov, A. V. Virovets, K. A. Brylev, R. A. Bredikhin, A. M. Maksimov, V. E. Platonov, and V. P. Fedin, Russian Chem. Bull., Int'l. Ed., 62 1764 (2013).

26. M. Prévôt, M. Amela-Cortes, S. K. Manna, R. Lefort, S. Cordier, H. Folliot, L. DuPont, and Y. Molard, Adv. Funct. Mater, 25, 4966 (2015).

27. F. Grasset, Y. Molard, S. Cordier, F. Dorson, M. Mortier, C. Perrin, M. Guilloux-Viry, T. Sasaki, and H. Haneda, Adv. Mater., 20, 1710 (2008).

28. T. G. Troung, B. Dierre, F. Grasset, N. Saito, N. Saito, T. K. N. Nguyen, K. Takahashi, T. Uchikoshi, M. Amela-Cortes, Y. Molard, S. Cordier, and N. Ohashi, Sci. Tech. Adv. Mater, 17(1), 443 (2016).

29. F. Grasset, F. Dorson, S. Cordier, Y. Molard, C. Perrin, A. M. Marie, T. Sasaki, H. Haneda, Y. Bando, and M. Mortier, Adv. Mater, 20, 143 (2008).

30. T. Aubert, F. Cabello-Hurtado, M. -A. Esnault, C. Neaime, D. Lebret-Chauvel, S. Jeanne, P. Pellen, C. Roiland, L. L. Polles, N. Saito, K. Kimoto, H. Haneda, N. Ohashi, F. Grasset, and S. Cordier, J. Phys. Chem. C, 117, 20154 (2013).

31. S. Cordier, B. Fabre, Y. Molard, A. B. Fadjie-Djomkam, P. Turban, S. Tricot, S. Ababou-Girard, and C. Godet, J. Phys. Chem. C, 120, 2324 (2016).

32. Y. Molard, C. Labbé, J. Cardin, and S. Cordier, Adv. Funct. Mater, 23, 1 (2013)

33. M. Amela-Cortes, A. Garreau, S. Cordier, E. Faulques, J.-L. Duvail, and Y. Molard, J. Mater. Chem. C, 2, 1545 (2014).

34. M. Amera-Cortes, S. Paofai, S. Cordier, H. Folliot, and Y. Molard, Chem. Commun, 51, 8177 (2015)

35. A. Barras, M. R. Das, R. R. Devarapalli, M. V. Shelke, S. Cordier, S. Szunerits, and R. Boukherroub, Appl. Catal. B: Environ., 130-131, 270 (2013).

36. P. Kumar, H. P. Mungse, S. Cordier, R. Boukherroub, O. P. Khatri, and S. L. Jain Carbon, 94, 91 (2015).

37. N. Koura, T. Tsukamoto, H. Shoji, and T. Hotta, Jpn. J. Appl. Phys., 34, 1643 (1995).

38. P. Sarkar and P. S. Nicholson, J. Am. Ceram. Soc., 79, 1987 (1996).

39. Y. Fukada, N. Nagarajan, W. Mekky, Y. Bao, H. -S. Kim, and P. S. Nicholson, J. Mater. Sci., 39, 787 (2004).

40. L. Besra and M. Liu, Progress in Mater. Sci., 52, 1 (2007).
41. J. J. Van Tassel and C. A. Randall, Key Eng. Mater., 314167 (2006).

42. I. Corni, M. P. Ryan, and A. R. Boccaccini, J. Europ. Ceram. Soc., 28, 1353 (2008). 43. M. Ammam, RSC Adv., 2, 7633 (2012).

44. A. Chávez-Valdez and A. R. Boccaccini, Electrochimica Acta, 6570 (2012).

45. F. Keller, H. Nirschl, W. Dörfler, and E. Woldt, J. Europ. Ceram. Soc., 35, 2619 (2015).

46. I. Zhitomirsky and L. Gal-Or, J. Mater. Sci.: Mater. Med., 8, 213 (1997).

47. M. Wei, A. J. Ruys, B. K. Milthorpe, and C. C. Sorrell, J. Biomed. Mater. Res., 45, 11 (1999).

48. M. Holgado, F. García-Santamaría, A. Blanco, M. Ibisate, A. Cintas, H. Míguez, C. J. Serna, C. Molpeceres, J. Requena, A. Mifsud, F. Meseguer, and C. López, Langmuir, 15, 4701 (1999).

49. B. Gao, G. Z. Yue, Q. Qiu, Y. Cheng, H. Shimoda, L. Fleming, and O. Zhou, Adv. Mater., 13, 1770 (2001)

50. A. R. Boccaccini, J. Cho, J. A. Roether, B. J. C. Thomas, E. J. Minay, and M. S. P. Shaffer, Carbon, 44, 3149 (2006).

51. J. Cho, K. Konopka, K. Rozniatowski, E. García-Lecina, M. S. P. Shaffer, and A. R. Boccaccini, Carbon, 47, 58 (2009).

52. Z.-S. Wu, S. Pei, W. Ren, D. Tang, L. Gao, B. Liu, F. Li, C. Liu, and H.-M. Cheng, Adv. Mater, 21, 1756 (2009).

53. G. Anné, K. Vanmeensel, J. Vleugels, and O. Van der Biest, Colloids and Surf. A: Physicochem. Eng. Aspects, 245, 35 (2004).

54. S. Dor, S. Rühle, A. Ofir, M. Adler, L. Grinis, and A. Zaban, Colloids Surf. A: Physicochem. Eng. Aspects, 342, 70 (2009).

55. D. Hanaor, M. Michelazzi, P. Veronesi, C. Leonelli, M. Romagnoli, and C. Sorrell, J. Europ. Ceram. Soc., 31, 1041 (2011).

56. R. Kawakami, T. Yuasa, K. Ito, Y. Sato, Y. Mori, M. Adachi, and S. Yoshikado, J. Australian Ceram. Soc., 48, 236 (2012).

57. L. A. Ma and T. L. Guo, Ceram. Int., 39, 6923 (2013).

58. Y. Huang, D. K. Sarkar, and X.-G. Chen, Appl. Surf. Sci., 327327 (2015).

59. S. N. Hosseini, H. Salimijazi, and M. H. Fathi, Mater. Lett., 14316 (2015).

60. H. Zhu, H. Liu, I. Zhitomirsky, and S. Zhu, Mater. Lett., 14219 (2015).

61. I. Hod, W. Bury, D. M. Karlin, P. Deria, C. W. Kung, M. J. Katz, M. So, B. Klahr, D. Jin, Y. W. Chung, T. W. Odom, O. K. Farha, and J. T. Hupp, Adv. Mater., 26, 6295 (2014).

62. C. Streich, S. Koenen, M. Lelle, K. Peneva, and S. Barcikowski, Appl. Surf. Sci., 348, $92(2015)$

63. J. Liu, Z. Wu, T. Li, D. Zhou, K. Zhang, Y. Sheng, J. Cui, H. Zhang, and B. Yang, Nanoscale, 8, 395 (2016).

64. T. Uchikoshi and Y. Sakka, J. Am. Ceram. Soc, 91, 1923 (2008).

65. W. D. Ristenpart, I. A. Aksay, and D. A. Saville, Phys. Rev. E, 69, 021405 (2004)

66. V. R. Estrelalopis, Z. R. Ulberg, and S. A. Koniashvili, Colloid J. USSR, 44, 74 (1982).

67. M. Böhmer, Langmuir, 12, 5747 (1996)

68. L. J. Guggenberger and W. Sleight, Inorg. Chem., 8, 2041 (1969)

69. Y. Q. Zheng, Y. Grin, and H. G. von Schnering, Z. Kristallogr. NCS, 213469 (1998)

70. X. Zarate, E. Schott, L. Alvarado-Soto, and R. Ramirez-Tagle, Chem. Phys. Lett., 56739 (2013). 